\title{
DETERMINANT OF FRAUD IN GOVERNMENT AGENCY: EMPIRICAL STUDY AT THE FINANCE AND DEVELOPMENT SUPERVISORY AGENCY (BPKP) OF JAKARTA REPRESENTATIVE OFFICE
}

\author{
Barry Aditya Permana \\ Finance and Development Supervisory Agency (BPKP) \\ Halim Dedy Perdana \\ Lulus Kurniasih \\ Study Program of Accounting of Sebelas Maret University
}

\author{
ARTICLE INFORMATION \\ Article history: \\ Received July 30, 2016 \\ Revised Dec 23, 2016 \\ Accepted May 21, 2017

\section{JEL Classifications} \\ D73; K49

\section{Key Words:} \\ Appropriateness of Compensation; \\ Effectiveness of Internal \\ Control System; \\ Organizational Ethical Culture; \\ Fraud in Government Agency.
}

\section{DOI:}

10.21532/apfj.001.17.02.01.08

\begin{abstract}
The purpose of this study is to examine the influence of the appropriateness of compensation, the effectiveness of internal control systems and the organizational ethical culture on fraud in government agency. The dependent variable used in this study is fraud in government agency, while the independent variables used are the appropriateness of compensation, the effectiveness of internal control systems, and the organizational ethical culture. This study uses a sample of 105 respondents at BPKP Jakarta Representative Office. Sampling technique is conducted using convenience sampling method. Data analysis method used is multiple linear regression statistical analysis. Results of regression analysis show that the appropriateness of compensation has positive effect on the occurrence of fraud in government agency, the effectiveness of internal control system has negative effect on fraud in government agency, and the organizational ethical culture has no significant effect on fraud in government agency.
\end{abstract}

\section{INTRODUCTION}

Government agency, according to Indonesian Government Regulation No. 60 of 2008 on Government Internal Control System, is an element of the central government or an element of the local government. Government agency is an executive tool in achieving government objectives. Therefore, the entire apparatus of government agency have the main duties and functions that must be supported by ethical behavior. But in reality, there 
are still many apparatus in the government agency who commit fraud, both in central government and local government.

According to the Association of Certified Fraud Examinations (ACFE), Fraud is categorized into three groups: Financial Statement Fraud, Asset Misappropriation, and Corruption). The word corruption is derived from the Latin word "corruption" from the verb form "corrumpere" which means rot, corrupt, bribe, shake, twist.

Coordinator of Investigation and Publication of Indonesian Corruption Watch (ICW), Tama S. Langkun, said that in the first half of 2014, there were 308 cases of corruption with 659 suspects, and the state loss was amounted to IDR 3.7 trillion. Meanwhile, in the second half, there were 321 cases of corruption with 669 suspects, and the state loss was amounted to IDR 1.59 trillion. "Totally, in 2014 there were 629 cases of corruption with 1,328 suspects, and the state loss was amounted to IDR 5.29 trillion," he said. (Source: www.hukumonline. com, March 10, 2015).

Based on the latest data issued by Transparency International in 2015, Indonesia's Corruption Perceptions Index was ranked $88^{\text {th }}$ of 168 countries. The GPA is worse than neighboring countries such as Singapore, Malaysia and Thailand. The factors that inhibit the increased ratings are high levels of corruption in the sectors of law enforcement and politics.

Financial and Development Supervisory Agency (hereinafter referred to as BPKP) is a non-ministerial government institution. The role of BPKP is explicitly stipulated in Presidential Decree No. 192 of 2014 on the BPKP. In accordance with the Presidential Decree, BPKP is the Government Internal Control Apparatus (hereinafter referred to as APIP), which is subordinate and accountable to the President. Based on Government Regulation No. 60 of 2008, Article 59, on Government Internal Control System (hereinafter referred to as SPIP), BPKP serves as a builder of the implementation of SPIP. Therefore, BPKP as one of the agencies that play a role in preventing and finding fraud must first be clean and free from possible fraudulent actions committed by employees.

This study aims to examine and analyze the negative influence of the appropriateness of compensation, the effectiveness of internal control system (SPIP) and the ethical culture of organization on fraud in government agency. The differences of this research from the previous research conducted by Pramudita (2013), among others, are: 1) the object of this study is the employees of BPKP of Jakarta Representative Office, while the object of the previous research is conducted on 111 government employees in Salatiga; 2) the independent variables of this research are the appropriateness of compensation, the effectiveness of internal control systems (SPIP) and the ethical culture of the organization, while the independent variables of the previous research are the appropriateness of compensation, the effectiveness of internal control systems, the ethical culture of the 
organization, leadership style, the influence of organizational commitment, and law enforcement. The results of previous research show that leadership style, the effectiveness of internal control systems, the appropriateness of compensation and the ethical culture of the organization have negative effect on fraud in the government sector in Salatiga and organizational commitment and law enforcement have no effect on fraud in the government sector.

This research is expected to be useful as an input in an effort to prevent fraud in the BPKP by creating policies that can reduce the determinants of fraud.

\section{THEORETICAL FRAMEWORK AND HYPOTHESIS DEVELOPMENT}

\section{Fraud Theory}

Fraud is a legal concept that has a wide scope. The term fraud is frequently referred to as fraud in financial sector. Association of Certified Fraud Examiners (ACFE) mentions fraud as acts against the law done intentionally for a specific purpose (manipulating or providing false reports to the other party) by people from within or outside the organization for personal or groups' gain that directly or indirectly harm others.

According to Black's Law Dictionary, 1) fraud consists of some deceitful practice or willful device, resorted to withintent to deprive another of his right, or in some manner to do him an injury. As distinguished from negligence, it is always positive, intentional;
2) fraud, as applied to contracts, is the cause of an error bearing on a material part of the contract, created or continued by artifice, with design to obtain some unjust advantage to the one party, or to cause an inconvenience or loss to the other; 2) fraud, in the sense of a court of equity, properly includes all acts, omissions, and concealments which involve a breach of legal or equitable duty, trust, or confidence justly reposed, and are injurious to another, or by which an undue and unconscientious advantage is taken of another.

\section{Types and Classification of Fraud}

Association of CertifiedFraudExaminations (ACFE), as one of the associations in the USA that have major activities in the prevention and eradication of fraud, classifies fraud in three groups as follows.

\section{Fraudulent Statement}

Fraudulent statement includes actions taken by an officer or executive of a company or government agency to cover the actual financial condition by performing financial engineering in the presentation of its financial statements to gain an advantage or perhaps it can be analogized with the term window dressing.

\section{Asset Misappropriation}

Asset misappropriation is the abuse / theft / taking of company's or other parties' property or assets. Types of asset misappropriation, among others, are Larceny, Billing Schemes, Payroll Schemes, Expense Reimbursement Schemes, Check Tampering and Register Disbursements. 


\section{Corruption}

This type of fraud is prevalent in the public sector. Fraud in the form of corruption is difficult to detect because it is done by some people who collaborate in conducting the fraud. According to the ACFE, corruption is divided into conflict of interests, bribery, illegal gratuity and economic extortion..

\section{Fraud Triangle}

Fraud Triangle was first formulated by criminologist, Donald Ray Cressey, through his doctoral research. His dissertation at Indiana University entitled, "Criminal Violation of Financial Trust" (1950) analyzed the perpetrators of embezzlement. According to Fraud Triangle theory by Cressey (1953) in Tuanakotta (2007), fraud is caused by three factors: (1) pressure, (2) opportunity, (3) rationalization. This study uses the fraud triangle theory as the main theoretical basis.

Pressure is the motivation of individual employee to commit fraud due to the both financial and non-financial pressure, personal and organizational pressure (leadership, too heavy task, and others). Pressure is proxied by the variable of the appropriateness of compensation.

Opportunity is the possibility of fraud as a result of weak or ineffective control so as to open up the possibility of fraud. The causal factors of fraud due to weaknesses in an organization, among others, are the weaknesses of systems, policies, procedures, processes, and others which result in an employee has the authority or ability to exploit the weaknesses, so he can commit fraud. Opportunity is proxied by the variable of the effectiveness of the internal control system.

Rationalization is the attitude or thinking process by moral considerations of individual employees to rationalize the fraudulent action (Rae and Subramaniam, 2008). Fraud occurs due to the condition of local ethical values that drive or allow the occurrence of fraud. The consideration of fraudulent behavior is a consequence of the employee's personal integrity gaps or other moral reasoning. Rationalization occurs when a person or group of people build a justification for fraud. The perpetrators of fraud are usually searching for reasons to rationalize that what they do is theft or fraud. Rationalization is proxied by the variable of ethical culture of the organization.

\section{Causal Factors of Fraud \\ The appropriateness of compensation}

Compensation or salary is important for every employee of an organization as it is the reciprocal of effort / contribution he has done for the organization and used to meet daily needs. According to Handoko (1993) in Pramudita (2013), compensation is the provision of financial payments to employee as remuneration for the work he has carried out and as a motivation for the implementation of activities in the future. In addition, according to Hariandja (2002) in Pramudita (2013), compensation is one of the important elements 
that can affect the performance of employees, because compensation is a tool to meet the various needs of employees, so with the compensation provided the employees will be motivated to work harder.

According to the theory of Wexley and Yuki (2003: 133), an unfair or inadequate compensation and drudgery can support incidents of theft by workers, in this case is the theft of assets of the company or organization.

Based on the above description, compensation can be summed up as a reward for the services provided by the employee for his efforts to increase the productivity of the companies that affect the increase in corporate profits. In the current development, the compensation given by the company is linked to the performance so that the amount of compensation is adjusted to the performance provided by the employee. If the compensation awarded is unfairly, this will cause employees to perform acts of fraud that have and adverse impact on the company. It can be assumed that the higher the appropriateness of the compensation awarded, the lower the occurrence of fraud in government agencies.

\section{The effectiveness of internal control system}

There are some opinions regarding the definition of internal control systems, among others:

a. According to the Indonesian Accountants Association (hereinafter referred to as IAI) as stated in the PSA No. 69 (IAI, 2001: 319.2), internal control is a process that is run by a board of directors, management and other personnel of entities that are designed to provide reasonable assurance about the achievement of the three objective groups: (a) the reliability of financial reporting, (b) the effectiveness and efficiency of operations, and (c) the compliance with applicable laws and regulations.

b. According to Government Regulation No. 60 of 2008 concerning Government Internal Control System (chapter 1), internal control system is an integrated process of the actions and activities which are carried out continuously by the management and all employees to provide reasonable assurance on the achievement of organizational goals through effective and efficient activities, reliability of financial reporting, the safeguarding of state assets, and compliance with regulations and legislation.

The existence of effective internal control system can create reliable and accountable financial report and performance, improve compliance with regulations and legislation, and implement good asset security. Moreover, it can also avoid the potential for fraud in government agencies.

Therefore, a good internal control system in government agencies will reduce the level of fraud that can be done, otherwise if the quality of the internal control system is bad, it can be an opportunity for employees to commit fraud. The more effective the internal control in government agency, the lower the level of fraud. 


\section{Organizational ethical culture}

According to Michael Armstrong (2009) in Pramudita (2013), organizational culture, or corporate culture is the values, norms, beliefs, attitudes and assumptions on how people in organizations behave and do things that can be done. Value is what is believed by people to behave in organizations. Norm is an unwritten rule that regulates one's behavior. The definitions above emphasize that organizational culture is related to the subjective aspects of a person to understand what is happening in the organization. This can influence the values and norms that cover all business activities, which may occur unnoticeably.

Organizational ethical culture is a pattern of behavior or trust that has become a role model for all members of the organization. Behavior here is the behavior that is morally acceptable and legally correct. In an ethical organizational culture there is a commitment and ethical environment. In the study conducted by Rae and Subramaniam (2008) shows that in a more ethical environment, an employee will be more likely to perform or execute the rules of the company, and avoid acts of fraud within the agency.

This ethical environment can be assessed with the existence of ethical organizational culture and organizational commitment, so it can be said that if an institution has a low ethical organizational culture, it will encourage its employees to commit fraud.
Based on the above theory, it can be concluded that the better the organizational ethical culture in an agency, the lower the tendency of employees to commit fraud. And the worse the ethical culture prevailing in an institution, the higher the tendency of employees to commit fraud.

\section{HYPOTHESIS FORMULATION}

The appropriateness of compensation

Based on the research conducted by Pramudita (2013), the appropriateness of compensation has negative effect on the occurrence of fraud in the government sector. A more appropriate compensation received by employees of government agencies will be able to suppress the occurrence of fraud in the institution. Based on the description of the appropriateness of compensation and its effect on the occurrence of fraud in the government sector, the hypothesis can be formulated as follows:

$H_{1}$ : Appropriateness of compensation has negative effect on the occurrence of fraud in government sector.

\section{The effectiveness of internal control system}

According to the results of the research conducted by Pramudita (2013), the effectiveness of internal control system has negative effect on the occurrence of fraud in the government sector. The better the internal control of a government, the lower the tendency of fraud occurring, similarly, the lower the level of compliance with internal controls, the higher the level of fraud in the government sector. Based on the description of the effectiveness of 
internal control system and its influence on the occurrence of fraud in the government sector, the hypothesis can be formulated as follows.

$\mathrm{H}_{2}$ : Effectiveness of internal control system has negative effect on the occurrence of fraud in government sector.

\section{Organizational ethical culture}

According to the results of the research conducted by Pramudita (2013), organizational ethical culture has negative effect on the occurrence of fraud in government sector. The better the organizational ethical culture of an agency, the lower the level of fraud occurring, similarly, the worse the organizational ethical culture of an agency, the higher the tendency of fraud occurring. Based on the description of the organizational ethical culture and its influence on the occurrence of fraud in the government sector, the hypothesis can be formulated as follows.

$H_{3}$ : Organizational ethical culture has negative effect on the occurance of fraud in government sector.

\section{RESEARCH METHOD}

\section{Research Approach}

This research is classified as a quantitative research that aims to test a theory and shows the relationship between variables. The data used in this study are primary data. Data collection methods used is through questionnaire. The questionnaire contains about employees' perceptions of the factors that influence the occurrence of fraud in government sector. The questionnaires are distributed directly to the civil servants at BPKP of Jakarta Representative office in 2016.

\section{Population and Sample}

The population in this study is all civil servants at the BPKP Representative Office Jakarta Province. The method applied in the sampling is convenience sampling method. Convenience sampling is the gathering of information from the members of population who gladly give it (Sekaran, 2013). The rationale for this method is because it is easier and simpler, in addition to the limited number of employees who could be encountered to be the respondent due to the bustle of these employees.

The samples taken are civil servants at BPKP Representative Office of Jakarta who could be encountered by researchers and are willing to provide information / answer the questionnaire given by the researchers. The number of samples in this study is 105 . The number is considered sufficiently representative because it has the required number of samples of 30 to 500 (Sekaran, 2003). 105 is the number of all the functional position of the existing auditors of a total of 152 employees at BPKP Representative Office of Jakarta.

\section{Conceptual and Operational Definition of Variables}

The conceptual and operational definitions of variables are summarized in the following table. 
Table 1

Conceptual Definition

\begin{tabular}{|c|c|c|}
\hline SYMBOL & VARIABLE & MEASUREMENT \\
\hline $\mathrm{X} 1$ & Appropriateness of Compensation & Questionnaire (Likert Scale 1-5) \\
\hline $\mathrm{X} 2$ & $\begin{array}{l}\text { Effectiveness of Internal Control } \\
\text { System }\end{array}$ & Questionnaire (Likert Scale 1) \\
\hline $\mathrm{X} 3$ & Organizational Ethical Culture & Questionnaire (Likert Scale 1) \\
\hline $\mathrm{Y}$ & Fraud in Government Sector & Questionnaire (Likert Scale 1) \\
\hline
\end{tabular}

\section{Data Analysis Method}

The data analysis used in this study is a quantitative approach, where statistics serves as the main analysis tool. Statistical tool used in this research is multiple linear regressions assisted by statistical software SPSS 18. The statistical tool is used to find out the relationship between the independent variables and the dependent variable. The number of independent variables used is three (more than one). The model in this study can be described as follows.

The model in this study can be formulated as follows:

$\mathrm{Y}=\alpha+\beta \mathrm{X} 1+\beta \mathrm{X} 2+\beta \mathrm{X} 3+\varepsilon$

Description:

$\mathrm{Y}=$ Fraud in government agency $\alpha=$ Constant

$\mathrm{X} 1=$ Appropriateness of compensation

$\mathrm{X} 2$ = Effectiveness of internal control system

$\mathrm{X} 3=$ Organizational ethical culture

$\varepsilon=$ Error

\section{Results and Discussion}

\section{Distribution of Respondents' answers}

Distribution of respondents' answers is used to determine the frequency and variety of respondents' answers to the variable items or the question items in the questionnaire. Before analyzing and discussing the results of the study, the first is to present the distribution of respondents' answers for each item of variables in the study. The summary of the distribution of respondents' answers for each item of variables can be seen in the following table.

Table 2

Distribution of Respondents' Answers

\begin{tabular}{|c|c|c|c|c|c|c|}
\hline \multirow{2}{*}{ VARIABLE } & \multicolumn{5}{|c|}{ Percentage of Respondents' Answers } & \multirow[t]{2}{*}{ Average Answer } \\
\hline & 1 & 2 & 3 & 4 & 5 & \\
\hline Appropriateness of & & & & & & 2,83 \\
\hline Compensation & $12 \%$ & $29 \%$ & $23 \%$ & $35 \%$ & $1 \%$ & \\
\hline Effectiveness of Internal & & & & & & 3,82 \\
\hline Control System & $1 \%$ & $6 \%$ & $14 \%$ & $69 \%$ & $10 \%$ & \\
\hline Organizational Ethical & & & & & & 3,55 \\
\hline Culture & $2 \%$ & $13 \%$ & $18 \%$ & $62 \%$ & $6 \%$ & \\
\hline Fraud in government agency & $51 \%$ & $42 \%$ & $5 \%$ & $4 \%$ & $0 \%$ & 1,62 \\
\hline
\end{tabular}

Source: Processed Data, 2016 
According to the table 2, it can be seen that, for the variable of fraud in government agency, the majority of respondents $51 \%$ stated strongly disagree, followed by $42 \%$ who stated disagree. This means that the majority of respondents consider that the level of occurrence of fraud at BPKP Representative Office of Jakarta is low or seldom with an average value of 1.62 (scale $1-5)$.

For the variable of appropriateness of compensation, the respondents are divided into three equal categories. $35 \%$ of respondents agreed, 29\% disagreed and 23\% neutral. This may reflect that $35 \%$ of respondents feel that the compensation is appropriate, 29\% not appropriate, and 23\% neutral. Therefore, in general, respondents consider that the appropriateness of compensation at BPKP of Jakarta Representative Office is quite good, with an average value of 2.83 (scale 1-5).

For the variable of effectiveness of internal control system, $69 \%$ of respondents agree, $14 \%$ neutral, and $10 \%$ strongly agree. This means that the majority of respondents consider that the internal control system at BPKP of Jakarta
Representative office is quite effective, with an average value of 3.82 (scale 1-5).

For the variable of organizational ethical culture, $62 \%$ of participants agree, $18 \%$ neutral and $13 \%$ disagreed. This means that the majority of respondents consider that the organizational ethical culture at BPKP of Jakarta Representative office is quite good or ethical, with an average value of 3.55 (scale $1-5)$.

\section{Hypothesis Test}

Todetermine the effect of the appropriateness of compensation, the effectiveness of internal control system, and the organizational ethical culture on fraud in a government agency, it is necessary to use multiple linear regressions analysis model which is intended to determine the effect of independent variables on the dependent variable. From the classical assumption test results, it can be seen that multiple linear regression model can be used in this research. A summary of the results of multiple regressions test can be seen in the following table.

Table 3

Multiple Linear Regression Test Results

\begin{tabular}{lcc}
\hline \multicolumn{1}{c}{ VARIABLES } & $\begin{array}{c}\text { REGRESSION } \\
\text { COEFFICIENT }\end{array}$ & $\begin{array}{c}\text { SIGNIFICANCE } \\
\text { VALUE }\end{array}$ \\
\hline Constant & 3.127 & \\
Appropriateness of Compensation (X1) & 0.215 & 0.021 \\
Effectiveness of Internal Control System (X2) & -0.544 & 0.000 \\
Organizational Ethical Culture (X3) & -0.012 & 0.910 \\
$\mathrm{R}$ & 0.442 & \\
$\mathrm{R}^{2}$ & 0.195 & \\
Adjusted $\mathrm{R}^{2}$ & 0.171 & \\
F Value & 8.164 & 0.000 \\
\hline
\end{tabular}

Source: Processed Data, 2016 
The test results of multiple regression in Table 3 as a whole show that the adjusted R-square value of 0.171 , or $17.1 \%$, means that the variable of fraud in government agency can be explained by the variables of appropriateness of compensation, effectiveness of internal control systems and organizational ethical culture by $17.1 \%$, while the remaining $82.9 \%$ is explained by other variables which are not included in the regression model.

\section{DISCUSSION}

\section{The Appropriateness of Compensation}

The results of data processing show that the appropriateness of compensation has a positive influence on the occurrence of fraud in government agency. Thus, the first hypothesis (H1) is rejected. It can be seen that the variable of appropriateness of compensation has a probability of significance value of 0.021 which is under $\alpha=5 \%$. However, the value of the regression coefficient is 0.215 , which means that each increase of one unit of appropriateness of compensation will increase the occurrence of fraud in government agency of 0.215 .

This contrasts with the results of the research conducted by Pramudita (2013) in which the more appropriate the compensation received by the employees of government agency will be able to suppress the occurrence of fraud in the government sector. But it is also not in line with the research conducted by Faisal (2013) that the appropriateness of compensation does not affect the fraud in the government sector.

In addition to basic salary, employees at the BPKP also get performance benefits.
Performance benefits are granted by taking into account the achievements of employee's performance each month based on their position class. Position class is a class grouping as a result from a weighted vote of work consisting of class 1 (one) up to class 18 (eighteen) as one of the basis for the provision of the amount of the employee performance benefit.

Based on the conditions described above, it can be concluded that the compensation received by the employees of BPKP in the form of salary and performance benefits not only take into account the position class and length of service but also take into account the weight of the workload, making it more fair and reasonable.

However, most cases of fraud occurring in the government sector are committed by officials or employees who have a high salary. Based on the causes of fraud in Bologna (1993) in Soepardi (2010), it is described using GONE Theory, where there are four factors why people perform deviation: 1) Greed. It is associated with the greedy behavior which is potential in a person; 2) Opportunity. It is associated with the chance of authority that one has to make a deviation; 3) Need. It is associated with the desire to meet the lifestyle that he things reasonable; 4) Exposure. It is associated with the actions or the consequences faced by perpetrators of fraud when they are found to have committed fraud.

Based on the distribution of the respondents' answers, the compensation received has been satisfactory, but others find it unsatisfactory. The average dissatisfaction is shown by X1_1 
and X1 2 indicators that show the absence of compensation or bonuses on the work performance and success in implementing job well. However, the occurrence of fraud in BPKP of Jakarta Representative Office remains small, because there have been systems that oversee so that the chance of fraud is getting smaller.

\section{The Effectiveness of Intern Control System}

Based on the results of data processing, the effectiveness of internal control systems has an effect on the occurrence of fraud in government agency. Thus, the second hypothesis (H2) is received. This can be seen in the table of multiple linear regression where the $\mathrm{p}$-value of 0.000 is much smaller than 0.05 . This is consistent with the research conducted by Pramudita (2013) that the high effectiveness of the internal control system of employees can prevent the occurrence of fraud in the government sector.

To achieve effective, efficient, transparent, and accountable state financial management, the ministers / leaders of institutions, governors and regents / mayors shall exercise control over the implementation of the activities of government. The control over government activity is guided by the government regulation on the government internal control systems (SPIP) as stipulated in Government Regulation (PP) No. 60 of 2008.

Article 47, paragraph 1 of Government Regulation No. 60 of 2008, states that ministers / leaders of institutions, governors and regents / mayors are responsible for the effectiveness of the implementation of the internal control system in each environment. As a government agency, BPKP are obliged to implement the internal control system as a builder in addition to the implementation of SPIP.

The effectiveness of internal control system at BPKP of Jakarta Representative Office is included in the category of "effective". That is because BPKP of Jakarta Representative Office has an effective control environment, such as clear division of powers and responsibilities, good risk assessment in the form of the completeness of supporting evidence of transactions, good control activities in the form of institutional regulation and policy, good information and communication in the form of Accounting Information Systems accounting (SIA), and monitoring and evaluation of operational activities to assess the implementation of the internal control system of the agency.

The objective of the implementation of Government Regulation (PP) No. 60 of 2008 at BPKP Jakarta Representative office is to provide reasonable assurance on the achievement of the effectiveness and efficiency of achieving the objective of the activities, the reliability of financial reporting, the safeguarding of state assets, and the compliance with laws and regulations.

\section{Organizational Ethical Culture}

Based on the results of data processing, the organizational ethical culture has no effect on the occurrence of fraud in government agency. Thus, the third hypothesis (H3) is rejected. 
This can be seen in Table 3 where the $p$-value of 0.910 is much greater than 0.05 . This contrasts with the research conducted by Pramudita (2013) who found that better organizational ethical culture will suppress the occurrence of fraud in the government sector. On the contrary, it is in line with the research conducted by Najahningrum (2013) who found that there is no influence between organizational ethical culture and the tendency of fraud. In addition, the research conducted by Faisal (2013) also states the same thing that there is no influence between the organizational culture and the tendency of fraud.

BPKP has already had employee behavior rules in accordance with the Decision of the Head of BPKP No. KEP-1446 / K / SU / 2008 dated December 23, 2008 of the Code of Conduct of the Employee of BPKP. BPKP's Employee Code of Conduct is the guidelines of attitudes, behaviors, and actions of the employees of BPKP, in carrying out the tasks and relationships of everyday life.

This rule of behavior governs the obligations and prohibitions as individuals and community members, as citizens, as state officials and as state apparatus. Related to the implementation of the rule of behavior of the employees, BPKP has issued Regulation of the Head of BPKP No. 33 of 2013 dated October 31, 2013 about the Gratification Control System at BPKP environment. This rule describes types of gratification, duties and the rights of employees, gratuities object delivery, obligation of the Unit Chief, duties and rights of the Inspectorate, and the reporting of the implementation of gratification control systems. This regulation aims to:

a. increasing the awareness of the employee to report gratuities;

b. maintaining transparent and accountable environment to support the creation of a clean environment in providing services at BPKP;

c. building the integrity of the employees who are clean and free from corruption, collusion and nepotism.

According to Faisal (2013), there are two factors that can affect an individual to behave: internal factors and external factors. External factors are the factors which are derived from the stimulation or influence of environmental factors. Meanwhile, internal factors are the factors which are derived from the factors existing within the individual. The biggest influence within an individual comes from within the individual self (internal). It can affect an employee to commit fraud, such as greed, desire to have luxurious lifestyles, and more recognition for the work.

Thus, no matter how well the organizational ethical culture built by a government agency, if the employee still has a greedy attitude and wants luxurious lifestyles, fraud will still occur. But it can be minimized by periodic supervision of the management and all elements of the agency. If they find unethical acts, they can report and follow up.

\section{CONCLUSION}

This study examines the factors that influence the occurrence of fraud in government agency. 
These factors include the appropriateness of compensation, the effectiveness of internal control systems and the organizational ethical culture. Based on these results, it can be concluded that:

a. The appropriateness of compensation has positive effect on the occurrence of fraud in government agency, because according to some respondents, the compensation obtained has been satisfactory, but others find it unsatisfactory. The average dissatisfaction is shown by $\mathrm{X} 1 \_1$ and $\mathrm{X} 1 \_2$ indicators that show the absence of the provision of compensation or bonuses on the achievement and success in implementing a good job.

b. The effectiveness of internal control system has negative effect on the occurrence of fraud in government agency, because according to the respondents, the internal control system has been working effectively and can reduce the potential for fraud in government agency.

c. The organizational ethical culture has no effect on the occurrence of fraud in government agency, because no matter how well the organizational ethical culture that is built by the government agency, but if the employees still have a greedy attitude, want luxurious lifestyles, the potential fraud will still occur.

\section{Research Limitation}

1. The number of respondents in this study is only 105 respondents, and the data collected are based on the perception of employees at BPKP Jakarta Representative only, so there is still possibility that the results are biased.

2. The sampling method used in this study is a convenience sampling method due to the limited number of employees who could be met to be the respondent. The weakness of the use of this method is that the results may be biased, the generalizability is low, the reliability of the data obtained is doubtful.

\section{Suggestion}

1. In the subsequent studies, survey respondents can be applied for all employees working across representative offices in 33 provinces so that the research data will be more varied.

2. In the subsequent studies, the research object can be replaced by other BPKP representatives or other agencies besides BPKP so that the research results obtained will be more varied.

3. The subsequent studies can use or add more variables or factors other than those used in this study, such as leadership style, law enforcement, organizational commitment, information asymmetry and others.

4. For the subsequent studies, it is better to use purposive sampling method, a sampling technique which is based on characteristics defined on the target population which were adapted to the purpose or research problems

5. BPKP Jakarta Representative Office should be able to prevent the occurrence of fraud in the government sector by pressing the cause of the occurrence of fraud in the public sector among others, 
by: a) creating a system of appropriate, fair and reasonable compensation / bonus for employees by considering the workload and performance, and better job performance; b) evaluating, monitoring and improving the implementation of internal control system continuously at BPKP Jakarta Representative Office; c) enforcing the rules of conduct of employees of BPKP and providing sanctions for any violations that occur according to applicable regulations.

\section{REFERENCES}

Arikunto, Suharsimi. 2002. Prosedur Penelitian (Suatu Pendekatan Praktek). Jakarta: Rineka Cipta.

Association of Certified Fraud Examiners. 2006. Report to Nation on Occupational Fraud \& Abuse. The Association of Certified Fraud Examiners, Inc.

Ghozali, Imam. 2006. Aplikasi Analisis Multivariate dengan Program SPSS Cetakan IV. Semarang: Badan Penerbit Universitas Diponegoro.

Black's Law Dictionary. 1990. 6th Edition. St. Paul, MN: West Publishing Co Bologna, Jack. 1993. Handbook of Corporate Fraud. Boston: Butterworth-Heinemann.

Faisal, Muhammad. 2013. Faktor-Faktor Yang Mempengaruhi terjadinya Fraud di sektor pemerintahan (Persepsi Pegawai Pada Dinas Se-Kabupaten Kudus. Skripsi. Semarang: Program Sarjana Universitas Negeri Semarang.
Hall, James. 2007. Accounting Information System. Jakarta: Salemba Empat.

IAI. 2001. Standar Profesional Akuntan Publik. Jakarta: Salemba Empat.

Indriantoro, Nur dan Bambang Supomo. 2009. Metodologi Penelitian Bisnis Untuk Akuntansi Dan Manajemen. Yogyakarta: BPFE.

Najahningrum, Anik Fatun. 2013. Faktor-Faktor Yang Mempengaruhi Kecenderungan Kecurangan (Fraud): Persepsi Pegawai Dinas Provinsi DIY. Skripsi. Semarang: Program Sarjana Universitas Negeri Semarang.

Pramudita, Aditya. 2013. Faktor-Faktor Yang Mempengaruhi Terjadinya Fraud Di Sektor Pemerintahan (Persepsi Pegawai Pada Dinas Se-Kota Salatiga). Accounting analysis Journal.

Rae and Subramaniam. 2008. Quality Of Internal Control Procedures Antecedents And Moderating Effect On Organisational Justice And Employee Fraud. Managerial Auditing Journal Vol. 23 No. 2, 2008 pp. 104-124.

Republik Indonesia, PP nomor 60 tahun 2008 tentang Sistem Pengendalian Internal Pemerintah.

, PP Nomor 34 Tahun 2014 tentang Peraturan Gaji Pegawai Negeri Sipil. ,PeraturanPresidenNo 192 tahun 2014 tentang Badan Pengawasan Keuangan dan Pembangunan. 
, Peraturan Presiden

no 106 tahun 2014 tentang Kenaikan

Tunjangan Kinerja Badan Pengawasan

Keuangan dan Pembangunan.

Keputusan Presiden

Nomor 103 tahun 2001 tentang

Kedudukan, Tugas, Fungsi, Kewenangan,

Susunan Organisasi, dan Tata Kerja

Lembaga Pemerintah Non Departemen.

BPKP No 13 tahun 2014 tentang

Organisasi dan Tata Kerja Perwakilan

Badan Pengawasan Keuangan dan

Pembangunan.

, Peraturan Kepala BPKP

Nomor 33 Tahun 2013 tentang Sistem

Pengendalian Gratifikasi di Lingkungan BPKP. , Keputusan Kepala BPKP

No: KEP-1446/K/SU/2008 tentang Aturan Perilaku Pegawai BPKP.

Santoso, Singgih. 2003. Buku Latihan Statistik Parametrik. Jakarta: PT Elex Media Komputindo.

Sawyer, Lawrence B, Mortimer A. Dittenhofer dan James H. Scheiner. 2006. Sawyer's internal auditing. Jakarta: Salemba Empat.

Sekaran, Uma. 2003. Metode Penelitian Untuk Bisnis, Edisi keempat. Terjemahan Kwan Men Yon. Jakarta: Salemba Empat.

Sekaran, Uma. 2013. Research Method For Business : A Skill Building Approach, Sixth Edition. United Kingdom : John Wiley \& Sons Ltd.
Soepardi, Eddy Mulyadi. 2010. Peran BPKP dalam Penanganan Kasus Berindikasi Korupsi Pengadaan Jasa Konsultansi Instansi Pemerintah.

Subekti dan Tjitrosoedibio. 1973. Kamus Hukum. Jakarta: Pradnya Paramita.

Sulistiyowati. 2007. Pengaruh Kepuasan Gaji dan Kultur Organisasi Terhadap Persepsi Aparatur Pemerintah Daerah tentang Tindak Korupsi. Yogyakarta: Universitas Sanata Dharma.

Tuanakotta. 2007. Audit Forensik dan Audit Investigatif. Jakarta : Fakultas Ekonomi Universitas Indonesia.

Wexley dan Yuki. 2003. Perilaku Organisasi dan Psikologi Personalia. Ed. Shobaruddin. Jakarta: PT Rineka Cipta.

Wilopo. 2008. Pengaruh Pengendalian Internal Birokrasi Pemerintah dan Perilaku Tidak Etis Birokrasi terhadap Kecurangan Akuntansi di Pemerintahan: Persepsi Auditor Badan Pemeriksa Keuangan. Ventura vol. 11 no. 1. 
Barry Aditya P., Halim Dedy P., Lulus K. : Determinant of fraud in government agency: empirical study ..... Page 93-108 